\title{
Middle class exodus and democratic decay in the Philippines
}

\author{
C. Urbanski \\ Faculty of Asian Studies, The Australian National University, Acton 0200, Canberra, Australia
}

Few countries in the world can rival the Philippines as an example of a non-substantive democracy. Recent general elections have been marred by electoral irregularities while the election of increasing numbers of populist or elite figures raises the question of how Southeast Asia's first democratic republic can be so persistently undemocratic? While the variables behind this troubling observation are numerous and varied, this paper takes the position that one of the major factors leading to the poor-quality of democracy in the Philippines is the mass emigration of middle class Filipinos. This paper will consider the moderating role played by the middle classes in contemporary Southeast Asia and then identify how and to what extent the Filipino middle class has shrunk over the last decade. A key result has been the "parochialization" of the Philippine electorate, with voters remaining in the Philippines typically voting for populist candidates or along traditional patron-client lines. The political loss of Filipinos abroad has been exacerbated by the nature of the overseas absentee voting system, which is yet to provide a realistic channel for the majority of overseas Filipinos to cast their votes. It is difficult to imagine the Philippines achieving more than a minimalist democracy until significant reforms are enacted to retain middle class citizens and improve the absentee voting mechanism for Filipinos living abroad.

"Many things are best in the middle; and there, in a state, I care to be" Phocylides

"The most perfect political community is one in which the middle class is in control, and outnumbers both of
the other classes."
Aristotle

"One of the defining characteristics of the Philippine middle class is that they all want to get out" Senior Western Economist, Manila

\section{VOTING WITH THEIR FEET}

"You don't join a political organization, you line up at an embassy" 1 is the increasingly popular mantra for educated, middle class Filipinos who have become disillusioned by the nation's failure to achieve meaningful political reform and its consistently underperforming economy. The Philippines, recently described as the "most persistently undemocratic democracy in Asia" ${ }^{2}$, is one of several countries in the world caught in a

\footnotetext{
${ }^{1}$ Sheila Coronel of the Philippine Center for Investigative Journalism, as quoted by Perlez, Jane, (2002). "Educated Filipinos, Disillusioned at Home, Look Abroad for a Better Life." The New York Times. April 8, 2002.

${ }^{2}$ Fabros, Aya., Rocamora, Joel. \& Velasco Djorina (Eds.), (2006). Social Movements in the Philippines. Institute for Popular Democracy. Philippines.p.28.
}

"powerful authoritarian undertow" 3 where democracy has been overthrown or stifled and the state works not to generate public goods or govern in the interest of its people, but rather to "produce private goods for officials, their families and their cronies". ${ }^{4}$ The democratic breakthrough achieved at Epifanio De La Santos Avenue (EDSA) ${ }^{5}$ in 1986 now appears to be little more than a hiccup in the ongoing game of "musical chairs among the elite". 6 With the middle class who led the way at EDSA

\footnotetext{
${ }^{3}$ Diamond, Larry, (2008). "The Democratic Rollback: The Resurgence of the Predatory State". Foreign Affairs, March/April 2008.

${ }^{4}$ Ibid.

${ }^{5}$ Epifanio De La Santos Avenueis the major artery road in Metro Manila and site of the 1986 "People Power" movement that toppled former president Ferdinand Marcos.

${ }^{6}$ BusinessWorld, (1998). "12 years after EDSA, Democracy Still Wanting”, Business World. February 27, 1998.
} 
now leaving the country en masse, only a thin veneer of democratic choice remains for the vast and poor majority in South East Asia's first democratic republic. $^{7}$

How is it that after the optimism and momentum for political reform generated in 1986, the Philippines has reversed its democratic trajectory a mere twenty years later? The complete array of contributing factors are diverse and interacting; a complete analysis would no doubt incorporate an examination of economic development, social values, religiosity and the political legacy of previous colonial and post-colonial authoritarian governments. However, this paper will restrict itself in specifically exploring the Filipino middle class and how this stratum has influenced the nature of governance in the Philippines since 1986. I will argue that middleclass flight and the limited opportunity for overseas Filipinos to participate in the political process has led to greater parochialism and the perpetuation of a non-substantive democracy in the Philippines over the last two decades.

This paper will first consider the relationship between the middle class and the state from a political theory perspective and then assess whether there is evidence to support adopting such a perspective in a modern and regionally-specific context. Second, the nature of the Philippine middle class will be discussed and key demographic changes of the last twenty years will be investigated. Next these demographic changes in Filipino society will be analysed; the middle class contribution to political transformation will be particularly emphasized. This has historically seen a period of democratic breakthrough in 1986, to the current situation where a poor quality, elite dominated democracy exists. Finally, prospects for the establishment of a substantive democracy in the Philippines will be briefly considered along with potential policies that may improve the quality of democracy in the Philippines through bolstering the middle class.

Before continuing, two key concepts must be appropriately defined. First, what exactly is the middle class? According to Aristotle, "in every state there are three parts: the very prosperous, the very

\footnotetext{
${ }^{7}$ Franco, Jennifer C., (2000). Campaigning for Democracy: Grassroots Citizenship Movements, Lessthan-Democratic Elections, and Regime Transition in the Philippines. Institute of Popular Democracy, Philippines. p. 39.
}

needy, and the middle class." 8 Historically the middle class has been made up of the self-employed: skilled tradesmen and artisans. In the modern era, this group has grown to include professionals, managers, and administrators in both the government bureaucracy and private firms. ${ }^{9}$ The middle classes are typically educated and politically aware, though not necessarily politically active. Meanwhile they usually possess valuable technical competencies and organizational skills, ${ }^{10}$ which are highly prized in the political arena.

The second key concept is democracy. In defining this term, it is imperative to draw the distinction between democracy's procedural and substantive meaning. The term "democracy" usually describes any political system where leaders are elected by free and fair elections. ${ }^{11}$ However, given the troubling number of governments worldwide that have manipulated the electoral process in order to disenfranchise voters and disconnect the electoral outcome from the will of the people ${ }^{12}$, it is clear this definition is inadequate - or minimalist at best. Hence, this paper will adopt a substantive definition of democracy: that is, a form of democracy practiced in an environment of liberalism and constitutionalism, whereby participation and representation is meaningful and individuals have the opportunity to exercise their vote with confidence in the accuracy and legitimacy of the electoral process.

\section{THE MODERATE MIDDLE CLASS}

The relationship between the middle class and governance is perhaps best articulated in Aristotle's Politics. Here it is suggested that due to the moderate characteristics of the middle class, they are more likely to behave according to reason and less

\footnotetext{
${ }^{8}$ Apostle, Hippocrates G. \& Gerson, Lloyd P., (1986). Aristotle's Politics. p. 121.

9 Carandang, Ricky, (2004). "Shrinking Middle Class", Newsbreak. April 12, 2004.

${ }^{10}$ Ibid.

${ }^{11}$ Abueva, Jose V., (1997). "Philippine Democratization and the Consolidation of Democracy Since 1986 EDSA Revolution: An Overview of the Main Issues, Trends and Prospects" in Felipe Miranda, ed., Democratization:

Philippine Perspectives.

${ }^{12}$ While "the people" is a contested term, here it is used as shorthand to broadly describe the members of a given political entity.
} 
disposed to the ruthless pursuit of power. ${ }^{13}$ The middle class plays a balancing role in the political system; they are able to join with the lower class should there be need to open up the political process or achieve some degree of redistribution of wealth, while they can join with the upper class to oppose the threat of a tyrant emerging from the lower classes who threatens the status quo. ${ }^{14}$ In short, the "addition of the middle class to one of the other two classes tips the scale, preventing the remaining extreme class from becoming dominant." 15 One can conclude that the best form of political organization is where power is vested in the middle class and that the presence of a large middle class in society leads to political stability and good governance-relative to oligarchic or tyrannical forms of government. ${ }^{16}$ It follows thus, that a growing middle class will lead to a greater potential for democratic governance; this is to say that, the rise of a strong middle class is one of the "critical causal factors engendering democracy". 17

In South-East Asia, there is plenty of evidence to suggest that as the middle class grows and becomes educated, there is indeed significant pressure for democratization to occur. Since the 1980's, prodemocracy movements built largely around the middle class have been identified as a significant contributing factor to democratization across the region. ${ }^{18}$ In Thailand, democratic breakthrough was achieved in 1992 when the mobile-phone wielding middle class joined political protests in the country; while in Indonesia, the middle class eventually joined university students in calling for the resignation of former President Suharto in 1998. Likewise in the Philippines, democratic

\footnotetext{
${ }^{13}$ Apostle, Hippocrates G. \& Gerson, Lloyd P. (1986). Op cit. p. 122.

${ }^{14}$ Glassman, Ronald M., (1995). The Middle Class and Democracy in a Socio-Historical Perspective. pp. 13-14.

${ }^{15}$ Apostle, Hippocrates G. \& Gerson, Lloyd P., (1986). Op cit. p. 123.

${ }^{16}$ This is not to discount the potential for a more selfserving middle class. Indeed the actions of the middle class based anti-democratic "People's Alliance for Democracy" of Thailand in 2007 and 2008 exemplify this possibility, see Winichakul, Thongchai, (2008). "Antidemocracy in Thailand" New Mandala. On balance however, a strong middle class has been seen to promote democracy, see Glassman, (1997). The New Middle Class and Democracy in Global Perspective. p. 142.

${ }^{17}$ Glassman, Ronald M., (1997). Ibid. p. 142.

${ }^{18}$ Lee, Junhan, (2002). "Primary Causes of Asian

Democratization: Dispelling Conventional Myths", Asian Survey. Vol. 42. No. 6. pp. $821-837$.
}

breakthrough was achieved through the middle class-led "people power" movement in $1986 .{ }^{19}$

The stream of middle class led democratic movements in contemporary Southeast Asia reinforces the balancing role the middle class plays checking any excessive accumulation of power by either the rich or poor. It logically follows that if the middle class is weakened, this potential for political reform is lost and an oligarchy of the rich or "extreme democracy" of the poor becomes a more likely challenge to a substantive democratic system. $^{20}$

\section{'OFW' EXODUS}

There is evidence to suggest that the Filipino middle class is indeed shrinking. In both sheer numbers and relative influence, the middle class is losing ground in contemporary Philippine society. Attrition due to high rates of emigration is the most direct cause, though many are also slipping from middle to low income brackets in a society where the fruits of economic development continue to be unevenly distributed. While high profile families that have experienced growth in their real incomes in recent years, can afford to stay; ${ }^{21}$ for middle class families a choice must be made whether to "leave for greener pastures or slip one rung down the economic ladder" 22 . Today, approximately 8 million Filipino citizens, representing around ten per cent of the population are living abroad. The number of Overseas Filipino Workers (OFWs) departing the country grew annually from 36,000 in 1976 to almost 700,000 in $1991 .{ }^{23}$ As indicated in Figure $1^{24}$, this trend has shown no sign of abating.

Of note is the number of Filipinos who have departed the Philippines on a permanent basis. In 2003, approximately 2.7 million of the 7.4 million Filipinos overseas were migrants who had attained permanent residency or citizenship abroad. ${ }^{25}$

\footnotetext{
${ }^{19}$ BusinessWorld, (1998). Op cit.

${ }^{20}$ See Glassman, Ronald M., (1997). Op cit. p. 101.

${ }^{21}$ Perlez, Jane, (2002). Op cit. See also Carandang, Ricky, (2004). Op cit.

${ }^{22}$ Carandang, Ricky, (2004). Op cit.

${ }^{23}$ Ibid. By comparison, the population of the Philippines increased from 43,194,417 in 1976 to 73,091,778 in 1998. See The World Bank, (2008). World Development Indicators.

${ }^{24}$ Carandang, Ricky, (2004). Op cit.

${ }^{25}$ Javellana-Santos, Julie, (2003). "Immigrants may Vote, but Where are the Funds?" OFW Journalism Consortium.
} 


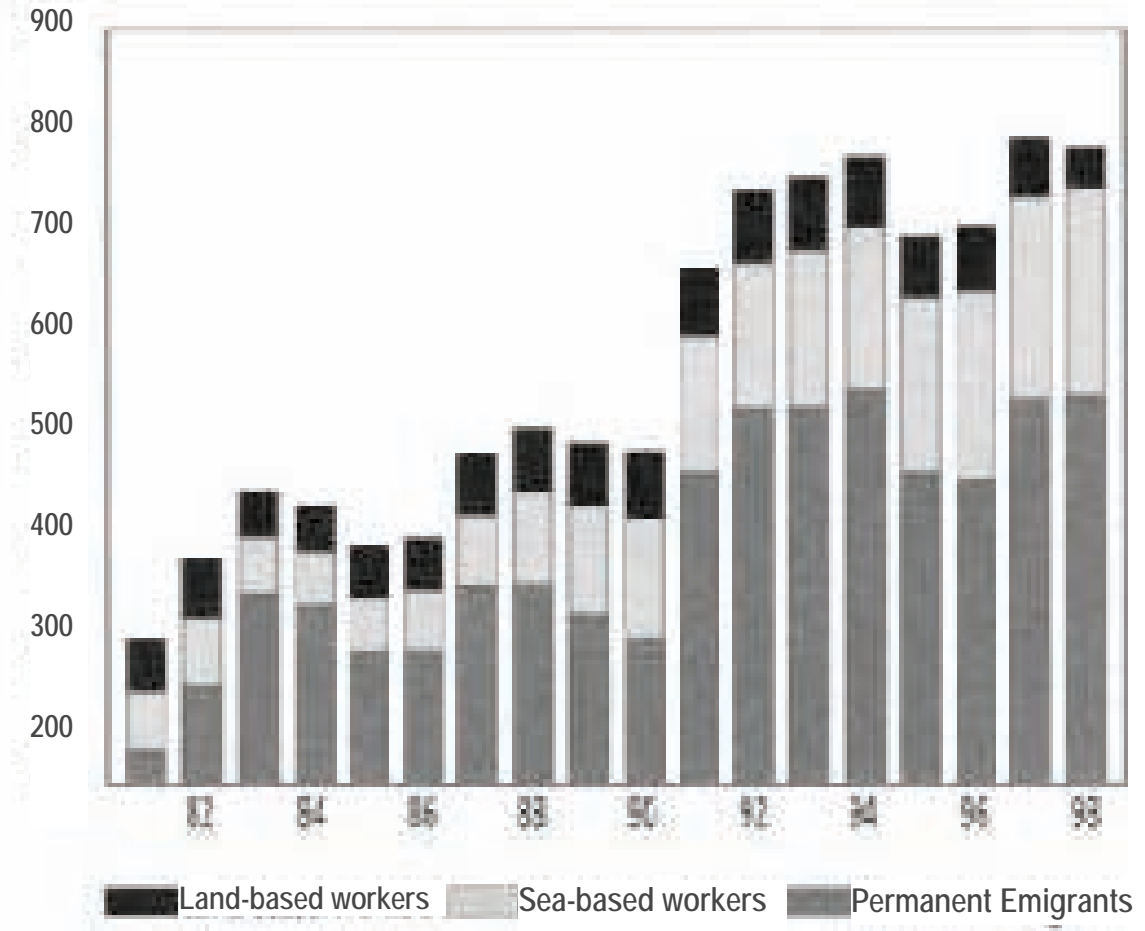

Fig. 1: Annual Flow of Filipinos to Foreign Destinations (in thousands, 1981-1998).
The dual impact of the middle class exodus and declining middle class incomes on the size and influence of the middle class has been empirically captured. In a recent empirical study by the National Statistical Coordination Board, ${ }^{30}$ it was shown that the middle class, fell from $23 \%$ of total families in 1997 to $19.9 \%$ of total families in 2003, as indicated in the Figure $2^{31}$ below. While the middle class has shrunk, the low income class has grown. This is significant, as it suggests that the electorate is increasingly composed of low income class voters.

Also significant is that Increasingly, those leaving the country are the educated middle classes. In the past the typical OFW was a Hong Kong nanny or a blue collar worker employed in construction or merchant shipping. ${ }^{26}$ In recent years however, the largest group of departing OFWs are the "professional and technical workers" of the middle class. ${ }^{27}$ Essentially, emigration is selective of the best educated and skilled individuals, which are typically drawn from the middle class. In 1975 , only $20 \%$ of the Philippines labour force had completed high school, while $80 \%$ of OFW's were high school graduates. Meanwhile in 1980, some $12.5 \%$ of the Philippine labour force had at least some college education, while $50 \%$ of the OFW population had some college education. ${ }^{28}$ In more recent times, between 1990 and 1999 it has been noted that the number of professional workers who went abroad actually exceeded the net additions of professionals to the labour force. ${ }^{29}$

\footnotetext{
${ }^{26}$ Perlez, Jane, (2002). Op cit.

${ }^{27}$ Wehrfritz, George \& Vitug, Marites, (2004). "Workers for the World; The Country's Prime Export is People. But is Migration a Real Development Strategy", Newsweek (International Edition). October 4, 2004.

${ }^{28}$ Battistella, Graziano. \& Paganoni, Anthony (Eds.), (1992). Philippine Labor Migration - Impact and Policy. Scalabrini Migration Center. See the chapter "Migrant Workers from the Philippines" by Carnio, Benjamin V.

${ }^{29}$ Ibid. See the chapter "Impact of Migration" by Vasquez, Noel.
}

while the proportion of middle class citizens is falling in total, it is the skilled tradesmen and young professionals in particular who are departing. Those left behind are predominantly of the "new middle class" variety. ${ }^{32}$ These employees are the salaried middle-managers and administrators in the bureaucracy or private firms; and as such do not enjoy the political freedom of the more independent

\footnotetext{
${ }^{30}$ Based on the results of the Family Income and Expenditures Survey conducted by the National Statistics Office (NSO) in the years 1997, 2000 and 2003. See Virola, Romulo A., Addawe, Mildred B. \& Querubin, Ivy T., (2007). "Trends and Characteristics of the Middle Income Class in the Philippines: Is it Expanding or Shrinking?" 10th National Convention on Statistics (NCS). October 1-2, 2007.

${ }^{31}$ Here we are using the distribution of families as a proxy for the distribution of citizens. This may be an imperfect method as there may not be a one to one conversion between class breakdown by family and by individual. However it is unlikely that in the six years to 2003 changes in the average family size of a particular class group could significantly skew the relationship between income distributions by family and per capita, meaning the data in figure II is a generally reliable barometer of the aggregate decline in the middle income class demographic. Source: Family Income and Expenditures Survey, National Statistics Office. See Virola, Addawe \& Querubin, (2007).

${ }^{32}$ For a complete discussion on the characteristics of the old and new middle class demographics, see Glassman, Ronald M. (1997). Op cit. Pp. 108-121.
} 


\begin{tabular}{|c|c|c|c|c|c|c|}
\hline \multirow{3}{*}{ Year } & \multicolumn{6}{|c|}{ Income Class } \\
\hline & \multicolumn{2}{|c|}{ Low } & \multicolumn{2}{|c|}{ Middle } & \multicolumn{2}{|c|}{ High } \\
\hline & Level & Percent & Level & Percent & Level & Percent \\
\hline 1997 & $10,881,914$ & 76.6 & $3,260,474$ & 23.0 & 50,074 & 0.4 \\
\hline 2000 & $11,598,258$ & 77.0 & $3,422,524$ & 22.7 & 51,160 & 0.3 \\
\hline 2003 & $13,172,033$ & 79.9 & $3,282,511$ & 19.9 & 25,849 & 0.2 \\
\hline
\end{tabular}

Fig. 2: Distribution of Families by Income Classes: 1997, 2000 and 2003. population, the proportion of total eligible voters they represent is significantly higher.

Essentially the migration of middle class Filipinos is a political loss. This is not to say that the middle class is "old" middle class. As career advancement and even job stability are directly linked to loyalty to the firm or government agency, many of these new middle class workers have simply been co-opted into "one white collar pyramid or another". ${ }^{33}$ In a country where both the machinery of government and the private sector are under the control of the elite, the opportunity of the Philippine middle class to play a balancing role in the political system has been severely undermined.

The reasons behind the middle class flight from the Philippines can be attributed to the poor performing economy, political instability, dissatisfaction with political reform as well as the effect of government labour and migration policy in facilitating the movement of labour overseas. In the interests of brevity, these factors cannot be explored in depth. However, we can conclude that due to changes in its composition and characteristics, the middle class has been shrinking both in size and political influence since it led the democratic breakthrough in 1986. The ongoing hemorrhage of these educated, politically aware Filipinos is "deprive[ing] their homeland of the chance to build a stable middle class and to crack a political system still encrusted with the oligarchs of the past." 34

\section{‘WOWOWEE VOTERS' AND THE LOST MIDDLE CLASS}

With almost eight million Filipinos living abroad on a temporary or permanent basis, there is a significant impact on the structure and nature of the electorate. It must be noted, that as the overwhelming majority of overseas Filipinos are workers, they represent a sector of the population that is almost entirely of voting age, compared to the domestic population which comprises a significant proportion of people below the legal voting age. What this means is that while the Philippines' diaspora includes some ten per cent of the total

\footnotetext{
${ }^{33}$ Ibid. p. 167

${ }^{34}$ Ibid.
}

not politically self-interested; but rather, that they tend be informed voters who are more independent and issues oriented. As these educated individuals leave the country however, the electorate becomes increasingly parochial. ${ }^{35}$ Indeed, it has been observed that overseas voters represent a "more sophisticated electorate" than those who remain in the Philippines. ${ }^{36}$ It is no surprise that so many former television personalities and action stars have been elected to office in recent years. ${ }^{37}$ Instead of informing voters of a candidate's policies and ideology, electoral campaigns have become little more than a popularity contest aimed at entertaining "Wowowee" voters in a shameless effort to win their support. $^{38}$

Moreover, low income voters are typically locked into existing patron-client relationships with local power brokers or elite families and tend to vote for the candidate that performs personalized constituent services as opposed to representing their long term or class political interests. ${ }^{39}$ Indeed, it has been found in the Philippines that the welfare of the poor is significantly reduced in provinces governed by a

\footnotetext{
${ }^{35}$ Battistella, Graziano. \& Paganoni, Anthony. (Eds.), (1992). Op cit. See the chapter "Impact of Migration" by Vasquez, Noel. p. 28

${ }^{36}$ Hogg, Chris, (2004). "Philippines: Fighting for the Migrant Vote", BBC News (Online), 22 March 2004.

${ }^{37}$ Some examples - among others - include Vice-

President Noli De Castro, Senator Loren Legarda, Senator Ramon Revilla Jr., former presidential candidate, Ferdinand Poe Jr. and former President, Joseph Estrada.

${ }^{38}$ Personal Observation, May 2007, Manila (Senate Election Campaign period). "Wowowee" is a popular midday television program that employs inane humour, cheap gimmicks, catchy music and provocative dancing to capture the short lived attention of its typically uneducated viewers. Some political rallies were not unlike the program in format.

${ }^{39}$ Velasco, Renato S., (1997). Op cit. Renato discusses the phenomena of the Comite de Silencio (Committee of Silence): congressmen who are always re-elected by their constituencies owing to patron-client relationships, despite their long and conspicuous silences when congress is in session.
} 
local dynasty. ${ }^{40}$ But while that is the case, many officials from longstanding political families with a strong local power base continue to be elected. ${ }^{41}$ Essentially, by offering short term incentives, or one-time personal favours, political elites can maintain their power across time and generations despite providing very little in the way of positive change for their poor constituents. These patronclient networks, built on the symbiotic relationship between maginoo (lord) and alipin (serf) play a crucial role in ensuring the electoral success of the oligarchic families who continue to dominate the legislature. $^{42}$

On the other hand, middle class Filipinos living abroad are perceived as being beyond the reach of local patron-client networks. When overseas Filipinos were finally given the opportunity to cast absentee votes in the 2003 elections, political observers expected a reinvigoration of the Philippine democracy as candidates and parties would have to compete to attract the votes of these 7-8 million Filipinos abroad. Described as "financially independent, issues oriented and not swayed by popularity... our lost middle class", ${ }^{43}$ these Filipinos represented something of a challenge to the oligarchic political families who have long dominated the political landscape. In essence, OFW's living abroad are the one demographic group who are free to vote objectively in elections and unlikely to be co-opted-or coerced-by local bosses or power brokers for their support.

While that is the case, the Overseas Absentee Voting Act (Republic Act No. 9189) ${ }^{44}$ has had little success in providing overseas Filipinos with a realistic avenue to participate in the electoral process. The Commission on Elections (COMELEC) mandated that voter registration and vote casting had to be done in person, ${ }^{45}$ at the nearest embassy or

\footnotetext{
${ }^{40}$ Balisacan, Arsenio, (2003). "Poverty and Inequality" The Philippine Economy: Development, Policies and Challenges. p. 334-335.

${ }^{41}$ The Aquino, Roxas, Osmena and De Leon families are each examples of intergenerational political families.

${ }^{42}$ Coronel, Sheila S., (2004). "How Representative is Congress?" Philippine Centre for Investagive Journalism.

${ }^{43}$ Araya, Jr., Alfred A., (2003). "Political Parties Face Challenge of Getting the Absentee Vote" OFW Journalism Consortium.

${ }^{44}$ Congress of the Philippines, (2003). Republic Act No. 9189: The Overseas Absentee Voting Act of 2003. Government of the Republic of the Philippines.

${ }^{45} \mathrm{Ibid}$. With the exception of Japan, Canada and the UK where postal ballots were trailed.
}

consulate. For OFWs in the USA and Middle East, the transport costs involved to do this were simply prohibitive. Meanwhile, overseas Filipinos who had attained permanent residency overseas were required to complete an affidavit indicating they intended to take up residence in the Philippines within the next three years. This condition also denied millions of citizens the right to vote. Given the restrictive nature of the act, it was unsurprising that in the 2004 election, just 356,000 OFW's registered to vote (with 65 per cent turning out on election day), while in 2007 just ten per cent of 540,000 registered overseas Filipinos voted ${ }^{46}$-this equates to just 54,000 votes counted out of almost 8 million OFWs.

From this analysis, we can draw the following two conclusions. First, the electorate is increasingly comprised of a greater proportion of parochial voters, who tend to cast their vote for patrons or populist figures that do not adequately represent their long term class political interests. ${ }^{47}$ Second, overseas Filipinos - predominantly of the middle class - have not been granted reasonable opportunity to participate in the electoral process. This has led to a form of democracy where all the trappings of the electoral process are upheld, but participation by informed voters has been severely eroded and representation of the needs and political aspirations of the majority low income class electorate has been usurped by sordid self-enrichment as the primary objective of many elected officials. Despite the groundswell of optimism for political reform expressed at EDSA in 1986, just two decades on, the Philippines has traded an autocrat for an oligarchy.

\footnotetext{
${ }^{46}$ Rojas, Henry S., (2007). "Overseas Absentee Voting: What Went Wrong?" ABC-CBN News.

${ }^{47}$ Since 1986 successive governments have come to power on a platform of pro-poor rhetoric that is rarely matched by policy efforts. High profile anti-poverty measures have been more concerned with scoring "pogi points" (brownie points) with the electorate rather than generating real welfare improvements. For example, the Comprehensive Agrarian Reform Programme (CARP) of the Aquino administration was aimed at combating rural poverty; the legislation however was systematically watered down and inadequately resourced by the landowner dominated legislature. Meanwhile, the "Lingap Para sa Mahihirap" (Looking after the poor) program of the Estrada administration was quite literally a pork barreling exercise where a range of benefits and subsidies were made available to the poorest 100 families of each province or city. See Balisacan, (2003). Op cit. pp. 312316.
} 


\section{THE PREDATORY PREDICAMENT}

How best then to achieve meaningful political reform and a substantive democratic system in the Philippines? Armed leftist movements built around the rural poor have proven unable to attract the mainstream support required to fundamentally alter the status quo ${ }^{48}$; while at the ballot box lower class voters continue to return elite candidates to office through voting along entrenched patron-client lines. It seems that any serious challenge to the ruling elite will require the ability, independence and leadership of the middle class in order to succeed. Furthermore, middle class participation must be sustained if a substantive democracy is to become the norm-and not an aberration-in the Philippine political landscape. We can conclude that one of the major barriers to democratization in the Philippines is the lack of a stable and politically active middle class that comprises a greater proportion of the population. Thus, perhaps the most effective strategy to increase the possibility of a high-quality democracy in the Philippines is to bolster the size of the middle class and help facilitate their participation in the political arena. This might be achieved through a number of approaches:

- First, expand the existing middle classparticularly those persons employed in occupations of the "old middle class" variety. This can be achieved through encouraging small business in the economy, for example by providing tax breaks or subsidies to small proprietors.

- Second, retain the existing middle class. With poor economic opportunity being a key push factor for emigration, it is essential to promote well paying and meaningful career opportunities for skilled Filipinos to ensure they remain in the country and are present to participate in the political system.

- Third, grow the middle class, through the promotion of low income earning families to higher income levels. This approach would require significant reform to health and education sectors, such as universal elementary and high school provided at little or no charge as well as medical and nutritional assistance for the poor.

- Lastly, reform the Overseas Absentee Voting Act. The present manifestation of the act disqualifies a great proportion of overseas Filipinos, while making the process of registration and voting unreasonably demanding for voters. A more inclusive system is required as well as universal access to postal voting if OFW votes are to be successfully captured in future elections.

Of course, the aforementioned policies are broad and overarching; their respective intricacies and the means by which to achieve them are the subject for other papers. However, one common feature shared by all these policies is that they rely upon the presence of a well-behaved government, which aims to maximize the welfare of its citizens. While the durability of even the most self-serving governments depends on engaging to some extent the aspirations of the citizenry, the exodus of middle class Filipinos as a political force has left the ruling oligarchs with little incentive to enact reforms. The Philippines is left facing a peculiar predicament: as long as it is dominated by an elite oligarchy, it is almost impossible to imagine the government undertaking measures to empower and grow an independent middle class which would inevitably form a bulwark of opposition against it. While as long as the middle class remains a weakened or insignificant actor in the political scene, the potentiality for the honest, free and representative practice of democracy remains extremely limited.

\section{ACKNOWLEDGEMENTS}

The author would like to thank Mr. Michael O'Shannassy and Dr. Nicholas Farrelly for their valuable comments.

\footnotetext{
${ }^{48}$ Leftist military groups such as the Hukbalahap and the New People's Army were significant threats to the government during the postwar period, but did not achieve the capacity required to seize power through hostile means. See Steinberg, David J., (1994). The Philippines: A Singular and a Plural Place. Pp. 113-114, 128-129, $160-161$.
} 


\section{REFERENCES}

Abueva, Jose V., (1997). "Philippine Democratization and the Consolidation of Democracy Since 1986 EDSA Revolution: An Overview of the Main Issues, Trends and Prospects" in Felipe Miranda, (ed.), Democratization: Philippine Perspectives, University of the Philippines Press, 1997.

Apostle, Hippocrates G. \& Gerson, Lloyd P., (1986). Aristotle's Politics. The Peripatetic Press. USA.

Araya, Jr., Alfred A., (2003). "Political Parties Face Challenge of Getting the Absentee Vote", OFW Journalism Consortium.

$<$ http://www.philippinestoday.net/ofwcorner/May03/ofw5 03_3.htm>._Accessed April 10, 2008.

Balisacan, Arsenio \& Hill, Hal (Eds.), (2003). "Poverty and Inequality" The Philippine Economy: Development, Policies and Challenges. Ateneo de Manila University Press. Manila.

Battistella, Graziano. \& Paganoni, Anthony (Eds.), (1992). Philippine Labor Migration - Impact and Policy. Scalabrini Migration Center. Philippines.

BusinessWorld, (1998). "12 years after EDSA, Democracy Still Wanting”, Business World (Weekender). February 27, 1998. <http://www.proquest.com>. Accessed April 5, 2008.

Carandang, Ricky, (2004). "Shrinking Middle Class", Newsbreak. April 12, 2004.

$<$ http://www.proquest.com>. Accessed April 5, 2008.

Congress of the Philippines. (2003). Republic Act No. 9189: The Overseas Absentee Voting Act of 2003. Approved February 13 2003. Government of the Republic of the Philippines.

Coronel, Sheila S. (2004). "How Representative is Congress?" Philippine Centre for Investagive Journalism Website.

$<$ http://www.pcij.org/stories/2004/congress.html. Accessed April 5 2008>.

Diamond, Larry. (2008). The Democratic Rollback: The Resurgence of the Predatory State. Foreign Affairs, March/April 2008. <http://www.foreignaffairs.org>. Accessed 31 April 2008.

Fabros, Aya., Rocamora, Joel. \& Velasco Djorina (Eds.), (2006). Social Movements in the Philippines. Institute for Popular Democracy. Philippines.
Franco, Jennifer Conroy, (2000). Campaigning for Democracy: Grassroots Citizenship Movements, Lessthan-Democratic Elections, and Regime Transition in the Philippines. Institute of Popular Democracy, Philippines.

Glassman, Ronald M., (1995). The Middle Class and Democracy in a Socio-Historical Perspective. E. J. Brill. Netherlands.

Glassman, Ronald M., (1997). The New Middle Class and Democracy in Global Perspective. Macmillan Press Ltd. Great Britain.

Hogg, Chris, (2004). "Philippines: Fighting for the Migrant Vote", BBC News (Online) 22 March 2004. $<$ http://news.bbc.co.uk/go/pr/fr/-/1/hi/world/asiapacific/345989>. Accessed 5 May, 2008.

Javellana-Santos, Julie, (2003). "Immigrants may Vote, but Where are the Funds?" OFW Journalism Consortium. $<$ http://www.philippinestoday.net/ofwcorner/February03/ ofw203_2.htm>. Accessed April 8, 2008.

Lee, Junhan, (2002). "Primary Causes of Asian Democratization: Dispelling Conventional Myths", Asian Survey, Vol. 42. No. 6. Pp. 821 - 837. University of California Press. $<$ http://www.jstor.org/stable/3038862>. Accessed April 4, 2008.

Velasco, Renato S., (1997). "Does the Philippine Congress Promote Democracy," in Felipe Miranda, ed., Democratization: Philippine Perspectives, University of the Philippines Press, 1997.

Virola, Romulo A., Addawe, Mildred B. \& Querubin, Ivy T., (2007). "Trends and Characteristics of the Middle Income Class in the Philippines: Is it Expanding or Shrinking?" 10th National Convention on Statistics (NCS). October 1-2, 2007. National Statistical Coordination Board (NSCB).

Wehrfritz, George \& Vitug, Marites, (2004). "Workers for the World; The Country's Prime Export is People. But is Migration a Real Development Strategy" Newsweek (International Edition). October 4, 2004.

$<$ http://www.proquest.com>. Accessed April 5, 2008.

Winichakul, Thongchai, (2008). "Anti-democracy in Thailand" New Mandala.

$<$ http://rspas.anu.edu.au/rmap/newmandala/2008/11/10/an ti-democracy-in-thailand/>. Accessed November 25, 2008.

The World Bank, (2008). World Development Indicators. $<$ http://ddp-

ext.worldbank.org/ext/DDPQQ/report.do?method=showR eport>. Accessed November 21, 2008. 